\title{
Dust exposure and pneumoconiosis in a South African pottery. 1 Study objectives and dust exposure
}

D Rees, R Cronje, R S J du Toit

\begin{abstract}
Dust exposure and pneumoconiosis were investigated in a South African pottery that manufactured wall tiles and bathroom fittings. This paper describes the objectives of the investigation and presents dust measurement data. $x$ Ray diffraction showed that the clays used by the pottery had a high quartz content (range $58 \%-23 \%$, mean $38 \%$ ). Exposure to respirable dust was measured for 43 workers and was highest $\left(6.6 \mathrm{mg} / \mathrm{m}^{3}\right)$ in a bathroom fitting fettler. Quartz concentrations in excess of $0.1 \mathrm{mg} / \mathrm{m}^{3}$ were found in all sections of the manufacturing process from slip production to biscuit firing and sorting. The proportion of quartz in the respirable dust of these sections was $24 \%$ to $33 \%$. This is higher than is usually reported in English potteries. Four hundred and six $(80 \%)$ of the 509 workers employed at the pottery were potentially at risk of occupational lung disease. The finding of large numbers of pottery workers exposed to unacceptable dust concentrations is not surprising as poor dust control was found in all six wall tile and sanitary ware factories surveyed by the National Centre for Occupational Health between 1973 and 1989. Dust related occupational disease can be expected in potters for many years to come.
\end{abstract}

Pneumoconiosis is a well established risk to workers manufacturing pottery wares. ${ }^{1}$ Despite this little has been published on the prevalence or nature of this disease among South African pottery workers. Published industrial hygiene data describing the raw materials used in South African potteries and dust concentrations in these workplaces are also scanty, making an assessment of the occupational health priorities in this industry difficult. To redress this

National Centre for Occupational Health, PO Box 4788, Johannesburg 2000, South Africa

D Rees, R Cronje, R S J du Toit lack of information a study was conducted in a large pottery to describe the raw materials used, to determine the current risk of exposure to excessive dust and to calculate the prevalence of pneumoconiosis.

As well as these major objectives, the relations between radiological abnormalities, dust exposure, smoking, and sex were investigated.

A further aim was to describe the radiological features in a series of cases of potters' pneumoconiosis. This was included because pottery dust usually contains at least two fibrogenic materialsnamely, quartz and kaolin ${ }^{2-4}$-and the radiological features of potters' pneumoconiosis may, therefore, differ from those typical of silicosis.

This paper presents the results of examination of the raw materials used by the pottery and the dust measurements. A companion article 5 presents the prevalence of pneumoconiosis and analyses of radiological findings.

Pottery such as wall tiles and sanitary ware are traditionally made from a mixture of clays, quartz or flint, and feldspar. ${ }^{6}$ In addition to these three major constituents $3-20 \%$ calcium or magnesium oxide is often added. Clays are the major constituent of wall tiles and sanitary ware and are usually kaolins (known as china clay if from Cornwall) or ball clays, ${ }^{7}$ both of which have kaolinite as the predominant mineral. High grade kaolins and ball clays are not readily available in many parts of South Africa. Consequently, clays with properties similar to kaolins and ball clays have been identified and are used in their place. A number of these clays are used in the production of a ceramic ware so that the different physical properties of clays from different deposits can be utilised and the natural variation within a single deposit accommodated. The quartz and kaolinite content of these "kaolin-like" clays have usually not been determined but are of interest as both quartz and kaolin cause pneumoconiosis in heavily exposed workers. ${ }^{2-4}$ The industrial hygiene survey of a pottery, reported in this paper, provided this mineralogical data for some clays. Also; respirable dust and quartz concentrations were measured so that the current risk of occupational lung disease and the relation between dust exposure and radiological abnormalities could be investigated. 


\begin{abstract}
Materials and methods
THE PRODUCTION PROCESS

The factory in which the survey was conducted manufactured both wall tiles and small bathroom fittings (such as soap dishes). The general manufacturing process for these articles was as follows: the raw materials were crushed and milled, and converted into a "slip" by the addition of water. After removal of impurities the slip was pumped through a press where "dewatering" occurred and the contained air was expelled. The resultant material is known as the ceramic body. The method adopted for shaping the body into the required product (ware) depended upon the complexity of the article. The more complex bathroom fittings were slip cast by liquifying the body (blunging) and pouring it into a plaster of Paris mould. The wall tiles were shaped by first drying the body to a "dust" (spray drying) and then pressing the dust in tile shaped dies (dry pressing). Once shaped, the blemishes and rough surfaces of the ware were removed by fettling or sponging.
\end{abstract}

The articles were fired before and after glazing. After the first firing the ware is known as "biscuit". The biscuit ware was glazed with a liquid glaze and fired. This second firing produces a ware known as "glost". The application of glaze to biscuit was by spraying for the bathroom fittings and by machine dipping for the wall tiles. The final process before packing and despatch was inspection to identify poor quality ware.

Besides the manufacture and glazing of wall tiles and bathroom fittings, the factory also produced floor tiles and refractory pieces for separating and supporting ware during firing, as well as manufacturing the glaze. The raw materials and production processes used in manufacture of glaze, floor tiles and refractory products were different from those used for wall tiles and bathroom fittings and are not considered in this paper. Wares were manufactured predominantly during one shift whereas firing and maintenance took place over a number of shifts. The work process was uniform and did not vary significantly from week to week. Housekeeping activity such as floor cleaning was done daily during the routine workshift. A personal protective equipment programme was not in place in the factory; consequently workers did not wear respirators during the performance of routine work.

\section{RAW MATERIALS}

The rough general formula for the wall tile and sanitary ware body used by this factory was clays $55 \%$, silica sand (quartz) $35 \%$, and calcium carbonate (calcite) $10-12 \%$. Broken biscuit was added to these raw materials.

Six or seven clays were used. Bulk samples of the clays were analysed at the National Centre for
Occupational Health ( $\mathrm{NCOH}$ ) using $x$ ray diffraction. The methods of Klug and Alexander ${ }^{8}$ and Bradley ${ }^{9}$ were used for this determination.

To confirm the $\mathrm{NCOH}$ findings from $x$ ray diffraction this investigation was repeated by an independent institution, the Council for Mineral Technology (MINTEK). A sample of production dust was analysed as well. The MINTEK $x$ ray diffraction was semiquantitative: minerals were categorised as major, minor, or trace constituents of the dust analysed. If a mineral constituted about $40 \%$ or more of the dust it was classified as a major constituent.

\section{DUST CONCENTRATIONS}

Exposure to dust was assessed as follows: (1) low dust areas were identified by walk through inspections conducted by a doctor experienced in occupational medicine, an industrial hygienist, and a factory management representative. Sections were classified low dust only if they were not directly involved in the production process and the doctor, the industrial hygienist, and the management representative found that they had low dust on inspection. To test this subjective evaluation personal breathing zone samples of respirable dust were collected from five workers in two of the low dust areas-namely, despatch and die shop. Quartz content of the samples was determined using $x$ ray diffraction. (2) The rest of the factory was classified as dusty and further assessed by collecting personal breathing zone samples of respirable dust from 38 workers and determining the quartz content of respirable dust for 12 of these samples using $x$ ray diffraction. Measurement of dust was conducted over two weeks during a period of usual production. An experienced industrial hygienist selected individual workers to wear personal dust samplers. The hygienist inspected each manufacturing section and selected workers thought to be representative of all the important procedures or jobs (tasks) performed in the section (random sampling such as that proposed by the US National Institute for Occupational Safety and Health ${ }^{10}$ was not adopted). Supervisors and cleaners who worked in more than one manufacturing section were categorised as general factory workers and were not selected to wear dust samplers.

Respirable dust concentrations in air in the workplace were determined by drawing a measured volume of air through a 25 or $37 \mathrm{~mm}$ diameter, $8 \mu \mathrm{m}$ pore size membrane or glass fibre filter. The filters were in Casella or BCIRA cyclone heads placed in the breathing zone of workers selected to participate and sampling times ranged from 228 to 293 minutes. The respirable $<7 \mu$ m dust thus collected was measured by weighing the filters before and after sampling. The procedure was as recommended by the UK Health and Safety Executive. ${ }^{11}$ Quartz content of respirable 
dust was determined using $x$ ray diffraction for 12 dust samples collected on $25 \mathrm{~mm}$ diameter membrane filters.

\section{Results}

MINERALOGICAL COMPOSITION OF CLAY AND

PRODUCTION DUST

The quartz content of six clays, as determined by $x$ ray diffraction at the $\mathrm{NCOH}$, was $58 \%, 42 \%, 35 \%$ $35 \%, 34 \%$ and $23 \%$ respectively. Table 1 shows the detailed composition of three of the clays. MINTEK $x$ ray diffraction confirmed that kaolinite and quartz formed major parts of all the clays and of the tile production dust (table 2 ).

Table 1 Mineralogical composition of clay

\begin{tabular}{llll}
\hline & \multicolumn{2}{l}{ Clay } & \\
\cline { 2 - 4 } Mineral & Glen White & Crous & Moss \\
\hline$\%$ Quartz & 58 & 42 & 35 \\
$\%$ Kaolinite & 20 & 35 & 36 \\
$\%$ Other & 22 & 23 & 29 \\
\hline
\end{tabular}

Table 2 Semiquantitative analysis of mineral composition of clays and production dust

\begin{tabular}{lllll}
\hline & \multicolumn{2}{l}{ Mineral } & & \\
\cline { 2 - 5 } Material & Quartz & Kaolinite & Sericite & Pyrophylite \\
\hline Glen White & major & major & trace & trace \\
Mayfield & major & major & trace & \\
Avenue park & major & major & minor & trace \\
Kuils & major & major & trace & \\
Crous & major & major & minor & trace \\
Moss & major & major & trace & minor \\
Production dust & major & major & trace & trace \\
\hline
\end{tabular}

\section{RESPIRABLE DUST AND QUARTZ CONCENTRATIONS IN} WORKPLACE AIR

Five personal dust samples were collected from the despatch and die shop areas; both of which were categorised as low dust during walk through inspections. Concentrations of respirable dust ranged from $0.02-0.4 \mathrm{mg} / \mathrm{m}^{3}$ with a median of $0.2 \mathrm{mg} / \mathrm{m}^{3}$. Quartz concentrations determined for these samples ranged from no quartz (undetected) to $0.03 \mathrm{mg} / \mathrm{m}^{3}$. These are below generally recommended upper limits for quartz exposure-for example, the threshold limit value (TLV) is $0.1 \mathrm{mg} / \mathrm{m}^{3} .^{12}$

A further 38 personal respirable dust samples were collected from workers in seven dusty manufacturing sections. Table 3 shows these manufacturing sections by respirable dust and quartz concentrations in air in the workplace.

Average respirable dust concentrations were similar in the seven dusty sections sampled with the median dust concentrations ranging from $0.9 \mathrm{mg} / \mathrm{m}^{3}$ (biscuit firing and sorting) to $2 \cdot 1 \mathrm{mg} / \mathrm{m}^{3}$ (bathroom fitting glazing). The range for individual workers was larger ranging from $0.2 \mathrm{mg} / \mathrm{m}^{3}$ (blunging in bathroom fitting section) to $6.6 \mathrm{mg} / \mathrm{m}^{3}$ (fettling of bathroom fittings). Concentrations varied within a single job category-for example, $1.2 \mathrm{mg} / \mathrm{m}^{3}$ to 6.6 $\mathrm{mg} / \mathrm{m}^{3}$ for the bathroom fitting fettlers. As shown in table 3, median dust concentrations were a conservative measure of average exposure to respirable dust as the mean dust concentrations were generally higher than median concentrations.

Quartz concentrations were determined for 12 of these 38 samples of respirable dust. In the sections glazing tiles and bathroom fittings the proportion of quartz in respirable dust was low $(7 \%$ and $8 \%$ respectively). In all other sections the percentage of quartz in the respirable dust was between $24 \%$ and

Table 3 Respirable dust and quartz concentrations by manufacturing sections and nature of work performed (job) in each section

\begin{tabular}{|c|c|c|c|c|c|c|}
\hline \multirow[b]{2}{*}{ Manufacturing section } & \multirow[b]{2}{*}{$J o b$} & \multicolumn{3}{|c|}{ Respirable Dust } & \multicolumn{2}{|c|}{ Quartz } \\
\hline & & No & range $m g / m^{3}$ & median (mean) $\mathrm{mg} / \mathrm{m}^{3}$ & No & median $m g / m^{3}(\%)$ \\
\hline Tile dust production & $\star$ & 3 & $0 \cdot 5-2 \cdot 1$ & $1 \cdot 2(1 \cdot 3)$ & 0 & - \\
\hline \multicolumn{7}{|l|}{ Bathroom fittings: } \\
\hline Fettling & & 4 & $1 \cdot 2-6 \cdot 6$ & $1 \cdot 8$ & 1 & $0 \cdot 17(30)$ \\
\hline Casting & & 4 & $0 \cdot 8-1 \cdot 3$ & 0.9 & 3 & $0.4(24)$ \\
\hline Total & & 9 & $0 \cdot 2-6 \cdot 6$ & $1 \cdot 2(1 \cdot 7)$ & & \\
\hline \multicolumn{7}{|l|}{ Tile making: } \\
\hline Tramping & & 2 & $1 \cdot 3-2 \cdot 8$ & $2 \cdot 1$ & 1 & $0 \cdot 16(26)$ \\
\hline Operating press & & 5 & $0 \cdot 7-1 \cdot 7$ & $1 \cdot 2$ & 2 & $0 \cdot 19(30)$ \\
\hline Feeding & & 2 & $1 \cdot 4-1 \cdot 6$ & 1.5 & 0 & 一 \\
\hline Total & & 9 & $0 \cdot 7-2 \cdot 8$ & $1 \cdot 4(1 \cdot 4)$ & & \\
\hline Biscuit firing and sorting & $\star$ & 5 & $0 \cdot 7-4 \cdot 2$ & $0.9(1.5)$ & 1 & $0.13(33)$ \\
\hline Bathroom fitting glazing & $\star$ & 2 & $0.9-3 \cdot 3$ & $2 \cdot 1(2 \cdot 1)$ & 1 & $0.07(8)$ \\
\hline All areas & & 38 & $0.2-6.6$ & $1.4(18)$ & & \\
\hline
\end{tabular}

^Numerous jobs prevented analysis by job. 
$33 \%$ and the TLV of $0 \cdot 1 \mathrm{mg} / \mathrm{m}^{3}$ was exceeded (table 3).

Table 4 shows the manufacturing sections of the pottery by degree of dustiness. Also shown are the number of workers employed in each section and the number who participated in the radiological component of the survey. Of the 509 workers, 173 $(34 \%)$ were in high dust sections. Maintenance and electrical section workers spent about half of their working day in the low dust workshops and the rest in high dust sections; they were, therefore, classified as intermittent high exposure. The glazing and glost sorting sections were classified as high dust/low quartz sections based on dust and quartz concentrations shown in table 3 . These 233 workers $(46 \%)$ in intermittent high or high dust/low quartz sections were potentially at risk of excessive dust exposure. Sixty four workers were employed in the sections of the factory in which no assessment of exposure to dust was performed.

\section{Discussion}

An important finding of this survey of a South African pottery was that quartz was a major constituent of all the clays analysed. By contrast, Georgia kaolin contains little, if any, quartz ${ }^{2}$ whereas commercial china clay contains over $90 \%$ kaolinite $^{3}$. It is premature to conclude that South African clay workers are exposed to unacceptable concentrations of quartz. These results do, however, suggest that this possibility requires investigation. The proportion of quartz in respirable dust in air in the workplace was higher than is usually reported in English potteries. For example two English studies found that the respirable fraction of dust generated during sanitary ware casting ${ }^{13}$ and fettling ${ }^{14}$ contained on average $12 \%$ and $18 \%$ quartz respectively compared with the $24 \%$ and $30 \%$ in this South African factory.

The survey also showed that unacceptably high respirable quartz concentrations were present in

Table 4 Exposure category by manufacturing section, number of workers employed, and number who participated in the survey

\begin{tabular}{|c|c|c|}
\hline Exposure category & No employed & No participating (\%) \\
\hline $\begin{array}{l}\text { Low: } \\
\text { Despatch } \\
\text { Application of transfers } \\
\text { Die shop } \\
\text { Laboratory } \\
\text { Screenmaking }\end{array}$ & $\begin{array}{r}17 \\
12 \\
5 \\
3 \\
2\end{array}$ & $\begin{array}{l}8(47) \\
5(42) \\
5(100) \\
2(67) \\
2(100)\end{array}$ \\
\hline Total & 39 & $22(56)$ \\
\hline $\begin{array}{l}\text { High: } \\
\text { Slip production } \\
\text { Tile dust production } \\
\text { Bathroom fittings } \\
\text { Tile making } \\
\text { Biscuit firing and sorting }\end{array}$ & $\begin{array}{r}22 \\
8 \\
28 \\
74 \\
41\end{array}$ & $\begin{array}{l}21(96) \\
6(75) \\
24(86) \\
66(72) \\
26(63)\end{array}$ \\
\hline Total & 173 & $146(84)$ \\
\hline $\begin{array}{l}\text { Intermittent high: } \\
\text { Maintenance } \\
\text { Electrical }\end{array}$ & $\begin{array}{r}40 \\
5\end{array}$ & $\begin{array}{r}31(78) \\
2(40)\end{array}$ \\
\hline Total & 45 & $33(73)$ \\
\hline $\begin{array}{l}\text { High dust/low quartz: } \\
\text { Tile glazing } \\
\text { Bathroom fitting glazing } \\
\text { Glost sorting }\end{array}$ & $\begin{array}{r}124 \\
4 \\
60\end{array}$ & $\begin{array}{r}75(60) \\
2(50) \\
35(58)\end{array}$ \\
\hline Total & 188 & $112(60)$ \\
\hline $\begin{array}{l}\text { No evaluation: } \\
\text { Floor tiles } \\
\text { Glazemaking } \\
\text { Refractories } \\
\text { Factory general } \dagger\end{array}$ & $\begin{array}{r}23 \\
14 \\
6 \\
21\end{array}$ & $\begin{array}{c}5(22) \\
14(100) \\
6(100) \\
12(57)\end{array}$ \\
\hline Total & 64 & $37(58)$ \\
\hline Overall total & 509 & $350 \ddagger$ \\
\hline
\end{tabular}

* Screens for decorating process similar to silkscreening.

$+=$ not located in a single department, exposure variable.

$\ddagger=358$ participated in total; incomplete information for eight workers. 
Table $5 \mathrm{NCOH}$ industrial hygiene reports on respirable dust exposure in the wall tile and sanitary ware industry

\begin{tabular}{|c|c|c|c|c|c|c|}
\hline \multirow[b]{2}{*}{ Report No } & \multirow[b]{2}{*}{ Major product } & \multirow[b]{2}{*}{$\begin{array}{l}\text { No of } \\
\text { samples }\end{array}$} & \multirow[b]{2}{*}{$\begin{array}{l}\text { No of } \\
\text { occupations }\end{array}$} & \multirow[b]{2}{*}{ Range $\left(\mathrm{mg} / \mathrm{m}^{3}\right)$} & \multicolumn{2}{|c|}{ Respirable dust concentrations } \\
\hline & & & & & $\%$ quartz (range) & $\begin{array}{l}\% \text { of samples } \\
\geqslant \mathrm{TLV}\end{array}$ \\
\hline $\begin{array}{rl}10 & 1973 \\
5 & 1974 \\
8 & 1974 \\
22 & 1986 \\
29 & 1987 \\
9 & 1989\end{array}$ & $\begin{array}{l}\text { Sanitary ware } \\
\text { Tiles } \\
\text { Sanitary ware } \\
\text { Sanitary ware } \\
\text { Tiles } \\
\text { Sanitary ware }\end{array}$ & $\begin{array}{r}15 \\
24 \\
24 \\
43 \\
6 \\
9\end{array}$ & $\begin{array}{r}9 \\
24 \\
14 \\
20 \\
4 \\
7\end{array}$ & $\begin{array}{l}0.42-3.54 \\
0.35-8 \cdot 41 \\
0.02-7 \cdot 69 \\
0.8-44 \cdot 2 \\
0 \cdot 5-1 \cdot 0^{\star} \\
0.38-2 \cdot 1\end{array}$ & $\begin{array}{c}28-39 \\
9-29 \\
4 \cdot 19 \\
10-60 \\
\text { Not done } \\
8-27\end{array}$ & $\begin{array}{c}100 \\
88 \\
63 \\
93 \\
17 \dagger \\
89\end{array}$ \\
\hline
\end{tabular}

*Author's note: "The rock crusher was not in use on the day of the survey . . . in the author's opinion there is no doubt that the (crusher) contributes considerably to the in-air dust level."

+ Estimated quartz content $8-20 \%$

many sections of the pottery. This finding is not surprising as historical industrial hygiene data contained in reports by $\mathrm{NCOH}$ show that unacceptably high dust concentrations were found in all wall tile and sanitary ware factories surveyed between 1973 and 1989. Table 5 summarises these reports. Dust concentrations were considered excessive if the TLV for quartz (calculated as $10 / \%$ respirable quartz +2 ) was exceeded. It should be noted when reading table 5 that particularly dusty jobs may have been selected for dust measurements thus artificially increasing the proportion of high dust jobs within each factory.

The assessment of respirable dust and quartz concentrations in the survey reported here had a number of limitations.

Limited resources meant that too few dust samples were collected to categorise every worker by dustiness of specific job performed (for example, cleaner, slip production). The best that could be achieved was a categorisation by manufacturing section of the factory (for example, slip production). The number of determinations of quartz was also limited.

This was the first industrial hygiene survey of the factory. No objective assessment of past dustiness could be obtained and current dust concentrations may be a poor index of past exposure for these workers as both the factory and the manufacturing process have changed with time. These changes probably resulted in only a modest reduction in dust, however, as no substantial dust control measures had been introduced for many years. More importantly, any reduction was probably fairly uniform because no manufacturing section had received particular attention.

Respirable dust concentrations were not measured in all sections classified as low dust during the walk through inspections. Nevertheless, where concentrations were measured (despatch and die shop) the subjective evaluation was shown to be a valid measure of dustiness as these areas had a median respirable dust concentration well below any of the manufacturing sections.
Despite these limitations a number of general conclusions can be reached: (1) the manufacturing process from slip production to biscuit firing and sorting generated respirable quartz concentrations above the TLV of $0.1 \mathrm{mg} / \mathrm{m}^{3}$. The proportion of quartz in respirable dust was fairly constant $(24-33 \%)$ for these sections and was much lower after biscuit sorting. (2) Average respirable dust concentrations did not vary greatly in the different manufacturing sections of the factory categorised as dusty during walk through inspections. (3) Areas classified low dust on subjective evaluation were less dusty than other sections.

Thus despite the limitations, the industrial hygiene data were adequate to achieve the objectives of the survey and allow division of workers into the exposure categories shown in table 4 . It can be concluded that certain pottery workers face a significant current risk of developing pneumoconiosis. This conclusion is probably generalisable to the whole industry as excessive dust concentrations were found in all potteries examined by $\mathrm{NCOH}$. Dust related occupational disease can be expected in potters for many years to come.

We thank the workers and management of the factory for their cooperation. Professor Davies and $\mathrm{Mr}$ Rendall gave valuable comment on earlier versions of this paper.

1 Meiklejohn A. The history of occupational respiratory disease in the North Staffordshire pottery industry. In: Davies CN, ed Health conditions in the ceramic industry. London: Pergamon Press, 1969:3-14.

2 Altekruse E, Chaudhary B, Pearson M, Morgan W. Kaolin dust concentrations and pneumoconiosis at a kaolin mine. Thorax 1984;39:436-41.

3 Wagner J, Pooley F, Gibbs A, Lyons J, Sheers G, Moncrieff C. Inhalation of china stone and china clay dusts: relationship between the mineralogy of dust retained in the lungs and pathological changes. Thorax 1986;41:190-6.

4 Morgan W, Donner A, Higgins I, Pearson M, Rawlings W, Bracken M. The effects of kaolin on the lung. Am Rev Respir Dis 1988;138:813-20.

5 Rees D, Steinberg M, Becker P. Dust exposure and pneumoconiosis in a South African pottery. 2 Pneumoconiosis and 
factors influencing the reading of radiological opacities. $\mathrm{Br} \mathrm{J}$ Ind Med 1992;49:465-71.

6 Singer F, Singer S. Industrial ceramics. London: Chapman and Hall, 1979:493.

7 International Labour Organisation. Encyclopaedia of occupational health and safety. Geneva: ILO, 1983:1775.

$8 \mathrm{Klug}$ HP, Alexander LE. $X-$ Ray diffraction procedures for polycrystalline and amorphous materials. New York: John Wiley and Sons, 1970.

9 Bradley AA. The determination of quartz in small samples by an $\mathrm{X}$-ray technique. Journal of Scientific Instruments 1967; 44:287-8.

10 National Institute for Occupational Safety and Health (NIOSH). Occupational exposure sampling strategy manual. Cincinnati, Ohio: NIOSH, 1977.

11 Health and Safety Executive. General methods for the gravimetric determination of total and respirable inhalable dust. MDHS 14. London: HMSO, 1986.

12 American Conference of Governmental Industrial Hygienists. Threshold limit values and biological exposure indices for 1990-91. Cincinnati: ACGIH, 1990.

13 Bloor WA, Eardley RE, Dinsdale A. Environmental conditions in sanitary whiteware casting shops. Ann Occup Hyg 1971; 14:321-7.

14 Higgins RI, Deere MR, Cinkotai FF. Fettler's exposure to pottery dust in a factory making sanitary whiteware. Ann Occup Hyg 1985;29:365-75.
15 National Centre for Occupational Health. Report on a survey of the health of employees and the conditions of employment with particular reference to exposure to silicosis dust in a ceramics factory producing sanitary ware. Johannesburg: NCOH, 1973. (NCOH rep 10/1973.)

16 National Centre for Occupational Health. Report on a survey of the health of employees and conditions of employment with particular reference to exposure to siliceous dust in a factory producing ceramic tiles. Johannesburg: $\mathrm{NCOH}, 1974$. (NCOH rep 5/1974.)

17 National Centre for Occupational Health. Report on a survey of the health of employees and the conditions of employment with particular reference to silicosis dust in a factory producing ceramic sanitary ware. Johannesburg: $\mathrm{NCOH}, 1974$. (NCOH rep $8 / 174$.)

18 National Centre for Occupational Health. Report on respirable dust and noise exposure at " a pottery". Johannesburg: $\mathrm{NCOH}$, 1986. (NCOH rep 22/1986.)

19 National Centre for Occupational Health. Report on respirable dust exposure at "a tile manufacturer". Johannesburg: NCOH, 1987. (NCOH rep 29/1987.)

20 National Centre for Occupational Health. Report on air monitoring at "a sanitary ware factory". Johannesburg: $\mathrm{NCOH}, 1989$. (NCOH rep 9/1989.)

Accepted 4 November 1991
The British Journal of Industrial Medicine welcomes correspondence relating to any of the material appearing in the journal. Results from preliminary or small scale studies may also be published in the correspondence column if this seems appropriate. Letters should be not more than 500 words in length and contain a minimum of references. Table and figures should be kept to an absolute minimum. Letters are accepted on the understanding that they may be subject to editorial revision and shortening.

The journal now also publishes editorials which are normally specially commissioned. The Editor welcomes suggestions regarding suitable topics; those wishing to submit an editorial, however, should do so only after discussion with the Editor. 